\title{
Correction to: The "State of Implementation" Progress Report (SIPREP): a pilot demonstration of a navigation system for implementation
}

Edward J. Miech ${ }^{1 *}$, Angela Larkin², Julie C. Lowery², Andrew J. Butler ${ }^{3}$, Kristin M. Pettey ${ }^{4}$, Nicholas A. Rattray ${ }^{1}$, Lauren S. Penney ${ }^{5}$, Jennifer Myers ${ }^{1}$ and Teresa M. Damush ${ }^{1}$

\section{Correction to: Implement Sci Commun 1, 102 (2020) https://doi.org/10.1186/s43058-020-00085-7}

Following publication of the original article [1], it was reported that the incorrect version of a reviewer's comments were published. The correct version has now been uploaded and the original article has been corrected.

\begin{abstract}
Author details
'VA Precision Monitoring to Transform Care (PRIS-M), Quality Enhancement Research Initiative, HSR\&D, Richard L. Roudebush VA Medical Center, Mail Code 11H, 1481 West 10th Street, Indianapolis, IN 46202, USA. ² VA Center for Clinical Management Research, VA Ann Arbor Healthcare System, 2215 Fuller Road, Ann Arbor, MI 48105, USA. ${ }^{3}$ School of Health Professions, University of Alabama at Birmingham, Dean's Office, SHPB 630, 1716 9th Avenue South, Birmingham, AL 35294, USA. ${ }^{4}$ VA Southeast Network Office (VISN 7), 3700 Crestwood Parkway, NW, Suite 500, Duluth, GA 30096-5585, USA. ${ }^{5}$ The Elizabeth Dole Center of Excellence for Veteran and Caregiver Research, South Texas Veterans Health Care System, 7400 Merton Minter, San Antonio, TX 78229, USA.
\end{abstract}

Published online: 03 December 2020

\section{Reference}

1. Miech EJ, Larkin A, Lowery JC, et al. The "state of implementation" Progress report (SIPREP): a pilot demonstration of a navigation system for implementation. Implement Sci Commun. 2020;1:102 https://doi.org/10. 1186/s43058-020-00085-7.

The original article can be found online at https://doi.org/10.1186/s43058020-00085-7.

*Correspondence: Edward.Miech@va.gov

'VA Precision Monitoring to Transform Care (PRIS-M), Quality Enhancement Research Initiative, HSR\&D, Richard L. Roudebush VA Medical Center, Mail Code 11H, 1481 West 10th Street, Indianapolis, IN 46202, USA

Full list of author information is available at the end of the article

C C The Author(s). 2020 Open Access This article is licensed under a Creative Commons Attribution 4.0 International License, which permits use, sharing, adaptation, distribution and reproduction in any medium or format, as long as you give appropriate credit to the original author(s) and the source, provide a link to the Creative Commons licence, and indicate if changes were made. The images or other third party material in this article are included in the article's Creative Commons licence, unless indicated otherwise in a credit line to the material. If material is not included in the article's Creative Commons licence and your intended use is not permitted by statutory regulation or exceeds the permitted use, you will need to obtain permission directly from the copyright holder. To view a copy of this licence, visit http://creativecommons.org/licenses/by/4.0/ The Creative Commons Public Domain Dedication waiver (http://creativecommons.org/publicdomain/zero/1.0/) applies to the data made available in this article, unless otherwise stated in a credit line to the data. 